\title{
21. THE HEAT FLOW ANOMALY IN THE NANKAI TROUGH AREA ${ }^{1}$
}

\author{
Hajimu Kinoshita, Department of Earth Science, Chiba University \\ and \\ Makoto Yamano, Earthquake Research Institute, University of Tokyo ${ }^{2}$
}

\begin{abstract}
Heat flow values were obtained from five DSDP holes (Leg 87) in the Nankai Trough, off the south coast of Shikoku Island, Japan. Heat flow values seem to be in good agreement with those obtained to date in this area. Some interpretations are given of the anomalously high values registered in the axial part of the trough compared to the adjacent area to the south.
\end{abstract}

\section{INTRODUCTION}

Geophysical and geologic studies of the ocean bottom around the Nankai Trough (off the south coast of Shikoku Island, Japan) reveal that the northern edge of the Philippine Sea Plate is subducting underneath the Japanese landmass along the Nankai Trough. The present subduction along this area is thought to have started only 3 to $5 \mathrm{Ma}$ ago, or even more recently (Moore and Karig, 1976), long after the cessation of the latest spreading along the Kinan Seamount ridge system to the west of the Iwo Jima Ridge about 15 Ma ago (Shih, 1980; Klein and Kobayashi, 1980). Distribution of earthquake epicenters (Shiono, 1977), seismic reflection profiles (Aoki et al., 1983), and lithologic distribution of old accretional materials (Leg 87 Scientific Party, 1983) imply a newly occurring subducting motion in this area. Heat flow distribution, however, shows unexpectedly high values along the deepest part of the Nankai Trough and becomes smaller to the north and to the south off the central part of the trough. Recently, Yamano and others $(1982 ; 1984)$ conducted a regional heat flow study around this area in combination with an investigation of the gas hydrate distribution revealed by seismic reflection surveys. Heat flow values obtained on the basis of this gas hydrate study and by ordinary spear-type heat flow probes showed fairly good agreement with each other. Leg 87 has provided us with 20 bottom-hole temperature measurements in the sediment layers. The hole locations were chosen close to the area where a décollement beneath the landward slope is well developed (site chapter, Site 583 , this volume). The heat flow values of $60-80 \mathrm{~mW} /$ $\mathrm{m}^{2}$ were predicted for the area around the holes from the distribution pattern compiled by Uyeda (1972), Watanabe and others (1977), Yoshii (1979), and Yamano and others (1982).

\footnotetext{
${ }^{1}$ Kagami, H., Karig, D. E., Coulbourn, W. T., et al., Init. Repts. DSDP, 87: Washington (U.S. Govt. Printing Office).

2 Addresses: (Kinoshita) Department of Earth Science, Faculty of Science, Chiba University, Chiba, Japan; (Yamano) Earthquake Research Institute, University of Tokyo, Bunkyo-ku, Tokyo 113, Japan.
}

\section{MEASUREMENTS OF BOTTOM-HOLE TEMPERATURES}

Bottom-hole temperatures were measured with two different instruments. The first instrument was developed at the Woods Hole Oceanographic Institution and successfully tested during DSDP Leg 86 (Horai and Von Herzen, in press). During the drilling of soft sediments contained in the topmost layer of the seafloor, this temperature device was installed in a thin wall of the cutting shoe of the hydraulic piston corer (HPC). Theoretical and practical aspects of this device are discussed in detail in the site chapter, Site 583 (this volume) and in Horai (in prep.) ${ }^{3}$. The only drawback of this instrument is the comparatively short battery life, which is probably due to a constant leakage of electric DC current through the surface of the battery-cell packages that were inadvertently moistened during operations. The other temperature probe is operated in combination with a Barnes water sampler (Yokota et al., 1980). To investigate whether the temperature values obtained through these two types of probes are compatible, one comparison test run was made during Leg 87, in which the Barnes water sampler probe (Uyeda probe) and the Woods Hole device (Von Herzen probe) were mounted together in the HPC cutting shoe in a single run (Fig. 1). Figure 2 shows the results (temperature versus operation-time plots) for both probes. This experiment is described in detail in the site chapter, Site 583 (this volume), and temperature data provided by both probes seem to be in good agreement. A detailed discussion of the thermal stability of the Von Herzen probe has been made by Horai (in prep.) ${ }^{3}$, on the basis of a simulation study of the thermal-state time variation around the bottom-hole probes. Horai showed that the temperature values of DSDP probes are reliable and that the accuracy is good to $\pm 6 \%$ of the obtained value only when a steady penetration of the probe sheath is attained. This result guarantees that if

\footnotetext{
${ }^{3}$ Horai, K., 1984. A theory of processing down-hole temperature data taken by the hydraulic piston corer of the DSDP.
} 


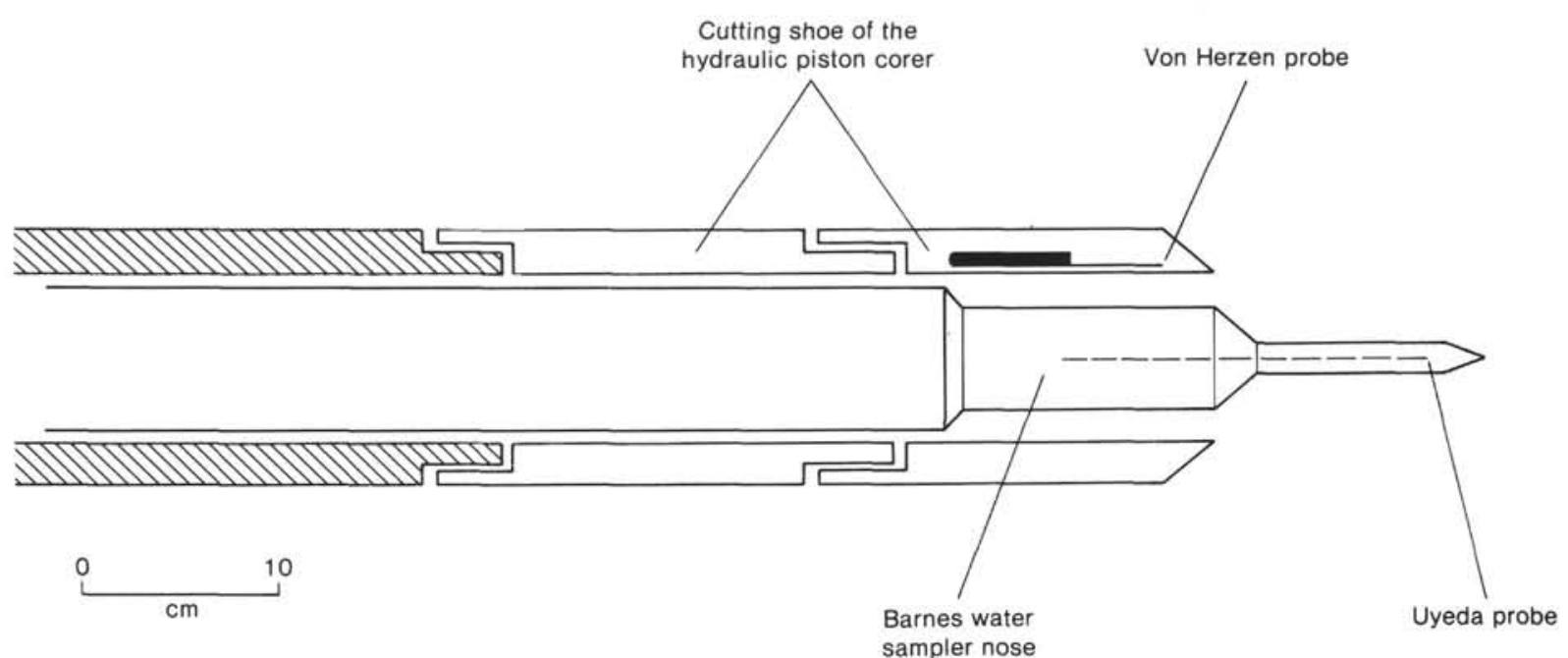

Figure 1. Cross section of alignment of two types of thermal probes. See text for more detailed description.

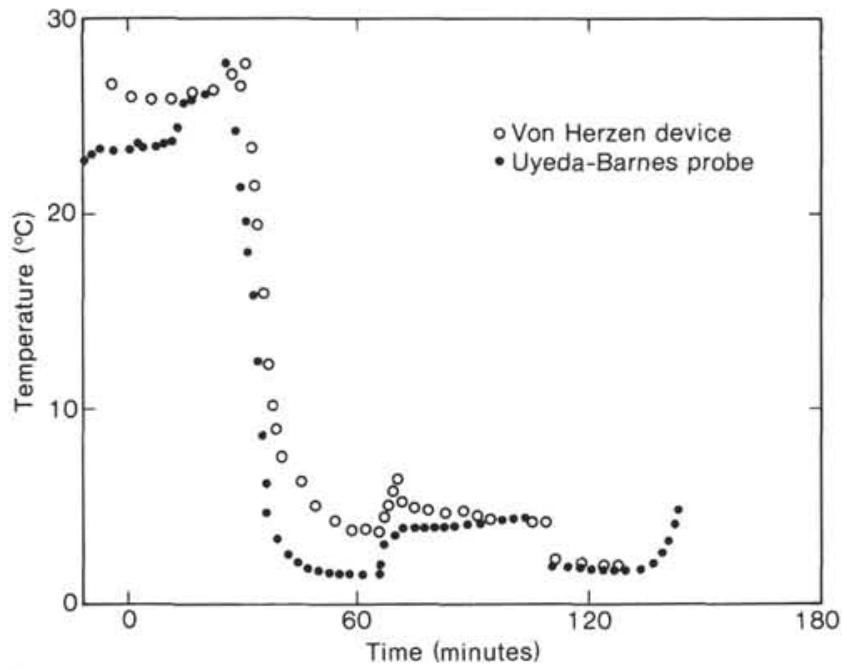

Figure 2. Temperature versus time curve showing the results of combination test run for comparison between Von Herzen and Uyeda probes (see Fig. 1). Test run was made at $55 \mathrm{~m}$ sub-bottom depth in Hole 583A.

the thermistor probe penetrates completely into the sediment and remains stationary, we can obtain real bottom-hole temperatures unaffected by drilling and subsequent flushing.

All the temperature data for Leg 87 are read, as usual, from the tail end of the decay curves after the sudden increase in probe temperature (which is due to the frictional heat generated by the "go-devil" penetration of the probe into the sediment). In some cases, we found mechanical difficulties and failure in the bottom-hole devices, and the temperature data were discarded as false even if the generated curve had a reasonable shape. Of the more-than-30 attempts at Sites 582 and 583, 20 operations were successful (Fig. 3). Sites 582 and 583 are different from each other not only in location but also in mudline water depths. Holes 582 through 582B are indistinguishable in their locations. Holes 583 through $583 \mathrm{~F}$ are closely clustered (within $600 \mathrm{~m}$ of each other) and, therefore, the temperature values from those holes are considered to belong to a single group. Water depths to mudline at Holes 582 through 582B are $4889 \mathrm{~m}$, and at Holes 583 through $583 \mathrm{~F}$ range from 4618 to $4687 \mathrm{~m}$. The sub-bottom depth shown on the plot in Figure 3 yields an ambiguity of plus-or-minus a few meters along the abscissa.

Thermal conductivities of sediments were measured on every undisturbed core by the needle probe method and were averaged. Thus, the mean downhole temperature gradient obtained by a least-squares fit to a straight line and the average thermal conductivity were multiplied to give an average heat flow value of the holes. Results and some parameters of the measurements are listed in the heat flow tables of the site chapters, Sites 582 and 583 (this volume).

\section{COMPARISON WITH OTHER RESULTS}

Heat flow values around the Nankai Trough off Shikoku Island (Fig. 4) are conspicuously high and evidently localized, although the eastern and western boundaries of the anomaly are not yet clearly defined. Yamano and others (1982) estimated heat flow from the Nankai Trough based upon the knowledge of gas-hydrate phase diagrams and on an average value of the thermal conductivity deduced in reference to the relations of $V_{p}$ (sonic velocity) versus $K$ (conductivity) of sediments. Their conclusion seems to be in good agreement with the distribution of heat flow obtained by conventional means.

The results of DSDP measurements (stars on Profile N55-3-1 in Fig. 4) are consistent with these data, especially the estimates based on the gas hydrate method along seismic reflection Profile N55-3-1. In addition to the heat flow data obtained up to 1982 by DSDP and by the use of gas hydrates, a recent cruise of the Hakuhomaru (University of Tokyo, KH-83-2 cruise) provided additional data (Yamano, unpublished data) by use of a multiple-penetration-type (POGO) apparatus (Hyndman et al., 1979) and corroborated our previous data concerning the existence of heat flow anomaly patterns within this area. 

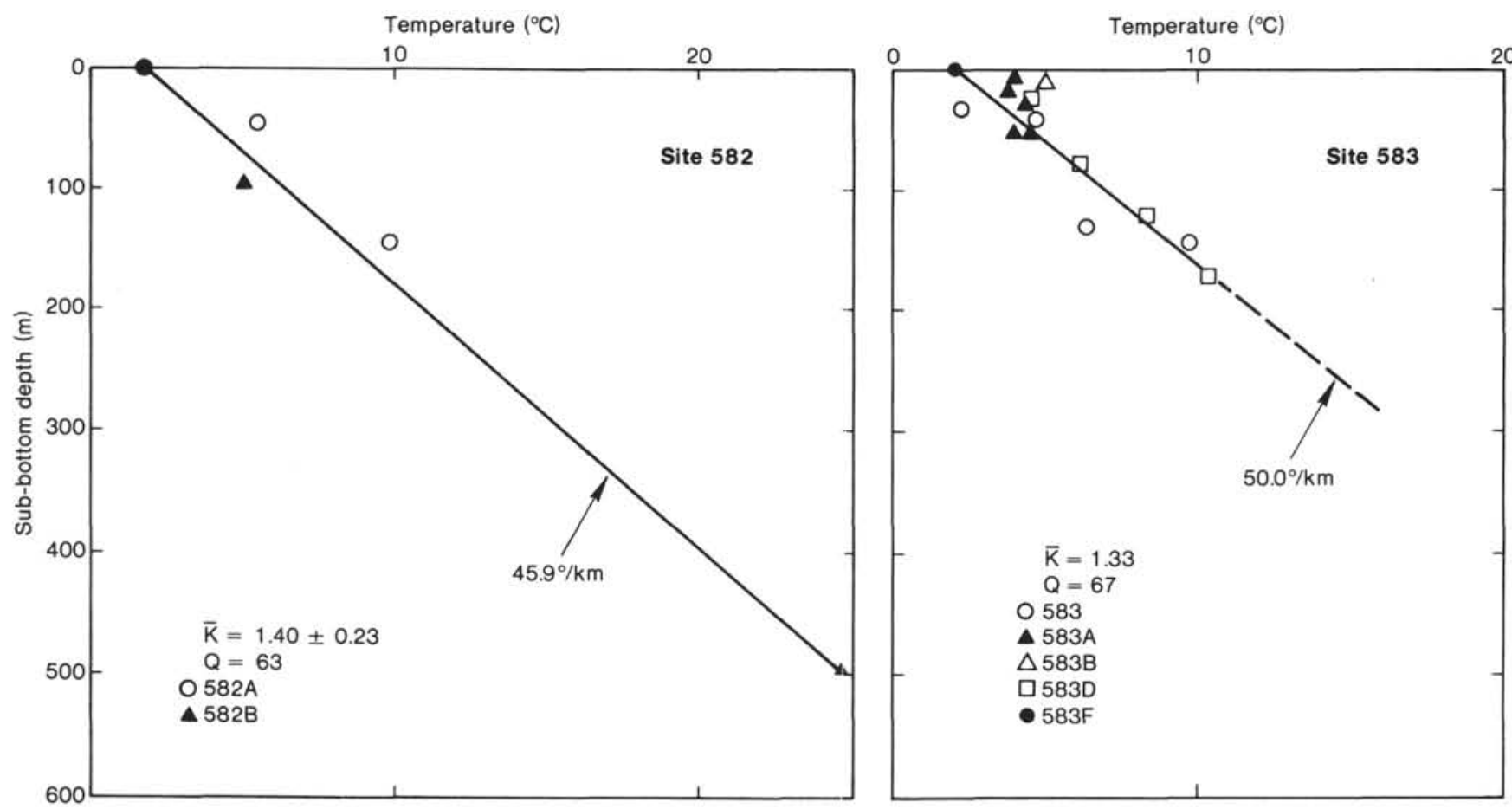

Figure 3. Distribution of temperature versus sub-bottom depth in Holes 582 and 583 . Temperature gradients are in $\mathrm{mK} / \mathrm{m}$. $\mathrm{K}=$ thermal conductivity in $\mathrm{W} / \mathrm{m} \mathrm{K} ; \mathrm{Q}=$ heat flow in $\mathrm{mW} / \mathrm{m}^{2}$.

\section{CAUSE OF HIGH HEAT FLOW IN THE NANKAI TROUGH AREA}

Heat flow in the Nankai Trough is conspicuously high compared with that in other trenches. It seems unreasonable that a trench system carries heat flow values higher than those on the adjacent lithosphere approaching the trench. However, there is no reason that the heat flow value of the trough area should be systematically low, if we take into account that the heat flow in the northern part of the Philippine Sea Plate offshore of the Nankai Trough is highly scattered $\left(20-150 \mathrm{~mW} / \mathrm{m}^{2}\right)$ and that depression of the trough itself is not excessive. Possibly, some relatively hot parts of the Philippine Sea Plate are showing up around the Nankai Trough area. However, the zone of high heat flow in the trough is wider and better defined than such zones observed further south off the Nankai Trough. Some specific causes might be (1) a hot plate, (2) mobility of a heat carrier through some structural boundary, and (3) chemical reactions in the deep-sea sediments.

\section{Hot Plate}

The subducting plate is assumed to be hot. In the Philippine Sea, several sets of active and remnant spreading-interarc-ridge systems exist. The southern half of the Mariana Trough is one of the active ridge systems as revealed by seismic studies (Ambos and Hussong, 1982; Hussong and Sinton, 1983; Karig and Ranken, 1983). The Kinan Seamount system (west of the Iwo Jima Ridge) is now inactive, but may have been one of the active spreading centers about 15-25 Ma ago (Kobayashi and Nakada, 1978; Shih, 1980). Moreover, some off-ridge volcanism accompanied by a number of small-scale lava in- trusions into the sediment layers occurred about $13-15$ $\mathrm{Ma}$ ago (Klein et al., 1978). If the heat-flow-versus-age law (Parsons and Sclater, 1977; Lister, 1977) is applicable to the Shikoku Basin, the highest possible heat flow value could reach the present value measured in the Trough $\left(150 \mathrm{~mW} / \mathrm{m}^{2}\right)$, although the higher values would require a still hotter lithosphere (Yamano et al., 1984).

In addition, comparison of this heat flow anomaly with other geophysical characteristics, such as the conductivity anomaly of central Japan (Rikitake, 1966; 1969) and the residual gravity anomaly (Tomoda and Fujimoto, 1983), suggests a deep origin of the heat flow anomaly (i.e., a hot subducting plate). The isotherms, which are drawn from regional heat flow values, are aligned parallel to the electrical conductivity distribution (Uyeda, 1972). Studies on the distribution of earthquake epicenters in this area clearly show that the dip angle of the Wadati-Benioff Zone to the north of the Nankai Trough is relatively low (dip angle $=10-20^{\circ}$, Shiono and Sugi, 1985). Some possible mechanisms that may account for a small dip angle are the high convergence rate (Luyendyk, 1970), the absolute motion of the landward plate toward the trench (Uyeda and Kanamori, 1979), and the buoyancy of the hot subducting plate (Sacks, 1983). The rate of convergence of the Philippine Sea Plate and the Japanese Islands is estimated to be between 2 and $6 \mathrm{~cm} /$ year (Seno, 1977; Kinoshita, 1980) based on accretion rate, earthquake slip-rate, and paleomagnetism. This value is low in comparison with those from other subduction zones, where the dip angles of the Wadati-Benioff zones are much higher. The absolute motion of the Eurasian Plate is slow, although its direction is not well determined (Minster and Jordan, 1978), so the component toward the Nankai Trough should be small, even if it is 


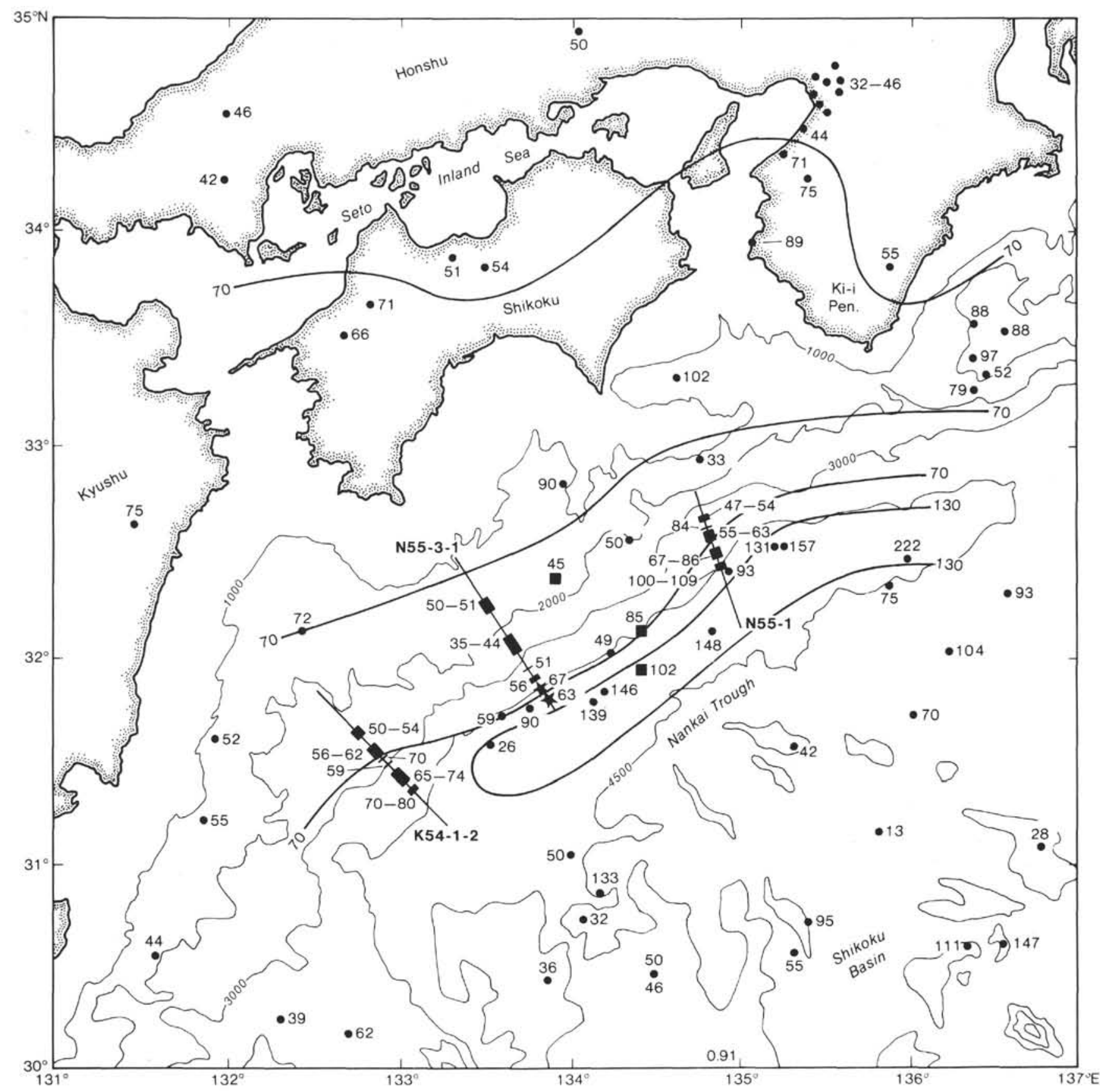

Figure 4. Heat flow distribution around the Nankai Trough area (in $\mathrm{mW} / \mathrm{m}^{2}$ ) mapped from a compilation of data (Uyeda, 1972; Watanabe et al., 1977; Yoshii, 1979; Yamano et al., 1984). Closed circles represent former measurements, stars represent the data obtained during Leg 87, and squares represent the data obtained on the KH-83-2 cruise. The data along three seismic reflection profiles, K54-1-2, N55-3-1, and N55-1, are estimated from gas hydrates.

positive. Therefore, the small dip angle of the subducting Philippine Sea Plate underneath Shikoku seems to be a result of the plate's buoyancy caused by its high temperature.

The fact that only the trough region reveals values comparable to or higher than those estimated from the heat-flow-versus-age law, whereas the other parts of the Shikoku Basin do not (Yamano et al., 1984), implies that the application of the general heat-flow-versus-age law to the Shikoku Basin may not be adequate to explain the high anomaly.
In young ocean basins, strong hydrothermal circulation gives scattered heat flow of low average values (Lister, 1972). As the ocean lithosphere gets older, the sediment cover develops and, as a result, in certain parts of the ocean basin, the transfer of heat by hydrothermal circulation is suppressed, bringing the heat flow close to the theoretical value (Anderson and Skilbeck, 1981). For example, geothermal measurements off the Costa Rica Rift (Becker et al., 1983) or the Taito Fracture Zone (off southern Chile; Herron et al., 1981) have confirmed that the steady heat flow value comparable to the theo- 
retical estimate can only be attained as the lithosphere moves sufficiently distant from the spreading center to carry a sediment cover thicker than 100-200 m. Results from DSDP Hole 504B show that a steady state of heat flow from the upper part of the crust is established shortly after the sediment cover develops (less than $5 \mathrm{Ma}$ for Hole 504B; Anderson et al., 1982; Becker et al., 1983).

If the same situation prevailed in the presently inactive spreading center of the Kinan Seamount ridge system, the topmost layer of the lithosphere could be partly cooled down by hydrothermal convection resulting in highly scattered heat flow values. This hypothesis is supported by the rugged topography with thin or missing sediment cover where the basement outcrops in the southern part of the Shikoku Basin. In the northern part, $100-200 \mathrm{~km}$ south or southeast from the Nankai Trough axis, basement rock is covered by comparatively thick sediment of terrigenous origin (Karig, 1975; Klein and Kobayashi, 1980). Within $200 \mathrm{~km}$ south of the trough axis, the topography is comparatively smooth and the basement layer sinks about $800 \mathrm{~m}$ toward the trough axis, carrying with it a maximum thickness of 700-800 m of overlying sediment layer at approximately $33^{\circ} \mathrm{N}, 135^{\circ} \mathrm{E}$ (Karig, 1975; Murauchi and Asanuma, 1977). Because the sediment cover thickened toward the trough axis owing to not only the high rate of terrigenous turbidite but also a deepening of the calcite compensation depth in the Quaternary, steady heat flow through the lithospheric plate was established.

Alteration of the topmost layer of the crust caused by hydrothermal reactions, if any, would have caused a dilatation of crustal material including cracks, faults, and substitutions for the original lithospheric materials and would have produced a layer permeable to fluids. This process would change the thermal properties of the topmost layer of the lithosphere and would accelerate the rate of heat transfer from there to the ocean floor. If we define the term "apparent thermal conductivity $\left(K_{\text {app }}\right)$ " as the ratio of the total amount of heat transfer (including heat transfer by fluid or equivalent carrier, in addition to normal conduction) to the thermal gradient, the $K_{\text {app }}$ of the topmost layer of the lithosphere is much higher than the normal conductivity $K$ beneath. This pattern occurs in Hole 504B (Anderson et al., 1982; Becker et al., 1983) and is probably also applicable to the present case. This means that the thermal time constant of the topmost layer should be much smaller than one calculated from normal thermal conduction, on the order of about $0.3 \mathrm{Ma}$, based on the assumption that the thickness of the sediment plus weathered crust equals $2000 \mathrm{~m}$, that the average density of this material is $3 \times 10^{3} \mathrm{~kg} / \mathrm{m}^{3}$ (a slight overestimate), that the specific heat is $10^{3} \mathrm{~J} /(\mathrm{kg}$ $\mathrm{K})$, and that the average thermal conductivity of the layer is $1.5 \mathrm{~W} /(\mathrm{m} \mathrm{K})$.

On the other hand, the $K_{\text {app }}$ of the substratum is much lower and the thermal time constant should be very large. The thickness of the solid lithosphere in this region is between 30 and $60 \mathrm{~km}$ (Kanamori and Abe, 1968; Shiono et al., 1980), equivalent to a time constant larger than $70 \mathrm{Ma}$.
This discussion leads us to a thermal model of the lithosphere around the Nankai Trough consisting of a double-layered structure. The thin topmost layer is exposed to the seawater for a certain period of time, and the heat flow values are depressed rapidly after cessation of ridge activity, while the underlying layer remains essentially hot. The thermal regime of the upper layer is highly variable depending upon surface conditions. As a spot approaches the trough axis, a thick sediment cover rapidly accumulates and the theoretical heat flow values are established.

The heat flow anomaly around the Nankai Trough might be caused, therefore, by a thermal "rebound" induced by the accumulation of a sediment cover overlying young lithospheric basement (this rebound will be called "heat rebound" hereafter). This heat rebound was observed in the temperature profile at Hole 504B after drilling through the sediment cover (Becker et al., 1983). Simulations of this effect are in progress.

\section{Mobile Heat Carrier}

Seawater may drain into the crust to the south of the trough cooling the lithosphere, only to well up along the trough carrying heat upward to the surface of the seafloor. This permeating fluid, however, must penetrate the thick sediment cover of the trough area $(300-800 \mathrm{~m})$. In the central part of the trough, the sedimentation rate is even higher (300-900 m/Ma; Leg 87 Scientific Party, 1983) than in other parts of the Philippine Sea Plate. The thickening of the sediment cover in the trough region will not only eliminate the possibility of the upwelling of hot water, but also may suppress heat flow by about $10-20 \%$ (Yamano et al., 1984; Langseth et al., 1980). A good example of this case occurs off the west coast of northern Oregon, where the heat flow is lower than expected theoretically from semi-empirical heat-flow-versus-age law, and the deviation is attributed to the high sedimentation rate (Yamano et al., 1984).

The mechanical squeezing of pore water out of deforming sediments during subduction is not powerful enough to generate a heat flow anomaly of the present magnitude (Yamano et al., 1984). Hence, we suggest an alternative mechanism, that is hydrologic circulation to produce high heat flow in the trough. Circulation is in the form of an advection current of small size within the area, specifically a type of hot-spring upwelling of a local underground stream. This fluid is warmed as it descends along the flanks of the continental shelf penetrating deep into the crust for reasons that are unknown. When it approaches the trough axis, it percolates through cleavage or fault planes in the crust of the ocean floor. During Leg 87, however, downhole temperature measurements did not reveal any indication of this kind of underground flow. However, postcruise recalculation of precise ship positioning (based on a comparison between the presite multichannel seismic reflection survey and the sonic log data obtained on board Leg 87) revealed that we might not have been stationed exactly on the location of the big fault produced by the décollement. This problem is discussed in detail by Aoki and others 
(this volume), and it does not preclude the possibility of hot water upwelling along the fault planes.

\section{Chemical Reaction}

A third possible explanation for the abnormally high heat flow remains. As the topographic chart indicates, the line of Sagami-Suruga-Nankai trench system seems to form a single continuous depression along the southern coast of the Japanese Islands, although a part of the depression is hidden by a landmass to the north of the Izu Peninsula. This portion may have been a part of a single linear trench in the geologic past, before the collision of the Izu Peninsula with the main island of Japan (Matsubara and Seno, 1980). An average of the numerous small sinusoidal fluctuations in water depth along the trench axis smooths the profile sufficiently to reveal a winding underwater valley with a gentle average slope of $0.2^{\circ}$. The terrigenous trench fill can probably flow constantly or episodically along the valley to reach and accumulate around the deepest part of the trench, the intersection of the Nankai Trough and the Ryukyu Trench, and there the sediment cover thickens abnormally. Some trench fill is trapped to the east of this junction owing to a comparatively high bank that forms the northernmost end of the Kyushu-Palau Ridge. The accumulation rate of the sediment is high near this ridge (about $1000 \mathrm{~m}$ / Ma or more), and all of the sediment could have been compressed and squeezed into a relatively narrow band of the trough (probably a few tens of kilometers) after the latest subduction began.

The trench fill contains organic matter, raw carbonate, and raw metals supplied from the land to the north. Leg 87 samples were gassy, probably the end product of the decomposition of organic material trapped in porous sediments under high confining hydrostatic pressures beneath the ocean floor. Heat produced through the decomposition or oxidation of organic matter beneath the ocean floor and similar effects on the local heat flow caused by decomposition and oxidation of sulfides are discussed by Kobayashi and Nomura (1972). Some of that discussion might be applicable to the high heat flow anomaly in the Nankai Trough.

\section{SUMMARY}

Measurements of the temperature gradient beneath the Nankai Trough during Leg 87 add to data acquired previously in this region. The contour map of the heat flow from the Nankai Trough region reveals a concentrated high heat flow anomaly reaching $160 \mathrm{~mW} / \mathrm{m}^{2}$, higher than the values estimated from the semi-empirical law of heat flow versus lithospheric age. A combination of the heat flow and other geologic and geophysical data from the area produce a model with a double-layered thermal state with respect to the heat transfer. This model suggests an initial cooling and a subsequent heating of the topmost layer of the lithosphere caused by the difference in the thermal time constant within the layer.

\section{ACKNOWLEDGMENTS}

We are grateful to Ki-iti Horai and Seiya Uyeda for their critical reviews.

\section{REFERENCES}

Ambos, E. L., and Hussong, D. M., 1982. Crustal structure of the Mariana Trough. J. Geophys. Res., 87:4005-4018.

Anderson, R. N., Honnorez, J., Becker, K., Adamson, A. C., Alt, J. C., Emmermann, R., Kempton, P. D., Kinoshita, H., Laverne, C., Mottl, M., and Newmark, R. L., 1982. DSDP Hole 504B, the first reference section over $1 \mathrm{~km}$ through layer 2 of the oceanic crust. Nature, 300:589-594.

Anderson, R. N., and Skilbeck, J. N., 1981. Oceanic heat flow. In Emiliani, C. (Ed.), The Sea, (Vol. 7): New York (Wiley-Interscience), 489-523.

Aoki, Y., Tamano, T., and Kato, S., 1983. Detailed structure of the Nankai Trough from migrated seismic sections. In Watkins, J. S., and Drake, C. L. (Eds.), Studies in Continental Margin Geology: Tulsa, Oklahoma (Am. Assoc. Pet. Geol. Mem.), 34:309-322.

Becker, K., Langseth, M. G., Von Herzen, R. P., and Anderson, R. N., 1983. Deep crustal geothermal measurements, Hole 504B, Costa Rica Rift. J. Geophys. Res., 88:3447-3457.

Herron, E. M., Cande, S. C., and Hall, B. R., 1981. An active spreading center collides with a subduction zone: a geophysical survey of the Chile Margin triple junction. In Kulm, L. D., Dymond, J., Dasch, E. J., Hussong, D. M., and Roderick, R. (Eds.), Nazca Plate: Crustal Formation and Andean Convergence: Boulder, Colorado (Geol. Soc. Am. Mem.), 154:683-701.

Horai, K., and Von Herzen, R. P., in press. Measurement of heat flow on Leg 86 of the Deep Sea Drilling Project. In Heath, G. R., Burckle, L. H., et al., Init. Repts. DSDP, 86: Washington (U.S. Govt. Printing Office).

Hussong, D. M., and Sinton, J. B., 1983. Seismicity associated with back arc crustal spreading in the central Mariana Trough. In Hayes, D. E. (Ed.), The Tectonic and Geologic Evolution of Southeast Asian Seas and Islands (Part 2): Washington (Am. Geophys. Union), Geophysical Monograph 27:217-235.

Hyndman, R. D., Davis, E. E., and Wright, J. A., 1979. The measurement of marine geothermal heat flow by a multipenetration probe with digital acoustic telemetry and in situ thermal conductivity. Mar. Geophys. Res., 4:181-205.

Kanamori, H., and Abe, K., 1968. Deep structure of island arcs as revealed by surface waves. Bull. Earthquake Res. Inst. Univ. Tokyo, 46:1001-1025.

Karig, D. E., 1975. Basin genesis in the Philippine Sea. In Karig, D, E., Ingle, J. C. Jr., et al., Init. Repts. DSDP, 31: Washington (U.S. Govt. Printing Office), 857-880.

Karig, D. E., and Ranken, B., 1983. Marine geology of the forearc region, southern Mariana island arc. In Hayes, D. E. (Ed.), The Tectonic and Geologic Evolution of Southeast Asian Seas and Islands (Part 2): Washington (Am. Geophys. Union), Geophysical Monograph 27:266-280.

Kinoshita, H., 1980. Paleomagnetism of sediment cores from Deep Sea Drilling Project Leg 58, Philippine Sea. In Klein, G. deV., Kobayashi, K., et al., Init. Repts. DSDP, 58: Washington (U.S. Govt. Printing Office), 765-768.

Klein, G. deV., and Kobayashi, K., 1980. Geological summary of the north Philippine Sea, based on Deep Sea Drilling Project Leg 58 results. In Klein, G. deV., Kobayashi, K., et al., Init. Repts. DSDP, 58: Washington (U.S. Govt. Printing Office), 951-961.

Klein, G. deV., Kobayashi, K., Chamley, H., Curtis, D. M., Dick, H. J. B., Echols, D. J., Fountain, D. M., Kinoshita, H., Marsh, N. G., Mizuno, A., Nisterenko, G. V., Okada, H., Sloan, J. R., Waples, D. M., and White, S. M., 1978. Off-ridge volcanism and seafloor spreading in the Shikoku Basin. Nature, 273:746-748.

Kobayashi, K., and Nakada, M., 1978. Magnetic anomalies and tectonic evolution of the Shikoku Inter-arc Basin. J. Phys. Earth, 26 (Suppl.):391-402.

Kobayashi, K., and Nomura, M., 1972. Iron sulfides in the sediment cores from the Sea of Japan and their geophysical implications. Earth Planet. Sci. Lett., 16:S200-S208.

Langseth, M. G., Hobart, M. A., and Horai, K., 1980. Heat flow in the Bering Sea. J. Geophys. Res., 85:3740-3750.

Leg 87 Scientific Party, 1983. Leg 87 drills off Honshu and SW Japan. Geotimes, 28(1):15-18.

Lister, C. R. B., 1972. On the thermal balance of a mid-ocean ridge. Geophys. J. R. Astron. Soc., 26:515-535. 
1977. Estimates for heat flow and deep rock properties based on boundary layer model. Tectonophysics, 41:157-171.

Luyendyk, B. P., 1970. Dips of downgoing lithosphere plate beneath island arcs. Geol. Soc. Am. Bull., 81:3411-3416.

Matsubara, Y., and Seno, T., 1980. Paleogeographic reconstruction of the Philippine Sea at 5 m.y.B.P. Earth Planet. Sci. Lett., 51: 406-414.

Minster, J. B., and Jordan, T. H., 1978. Present-day plate motion. J. Geophys. Res., 83:5331-5354.

Moore, J. C., and Karig, D. E., 1976. Sedimentology, structural geology, and tectonics of the Shikoku subduction zone, southwest Japan. Geol. Soc. Am. Bull., 87:1259-1268.

Murauchi, S., and Asanuma, T., 1977. Seismic Reflection in the Western Pacific, 1965-1974: Tokyo (University of Tokyo Press).

Parsons, B., and Sclater, J. G., 1977. An analysis of the variation of ocean floor bathymetry and heat flow with age. J. Geophys. Res., 82:803-827.

Rikitake, T., 1966. Electromagnetism and the Earth's Interior: Amsterdam (Elsevier).

, 1969. The undulation of an electrically conductive layer beneath the islands of Japan. Tectonophysics, 7:257-264.

Sacks, I. S., 1983. The subduction of young lithosphere. J. Geophys. Res., 88:3355-3366.

Seno, T., 1977. The instantaneous rotation vector of the Philippine Sea plate relative to the Eurasian plate. Tectonophysics, 42:209-226.

Shih, T. C., 1980. Magnetic lineations in the Shikoku Basin. In Klein, G. deV., Kobayashi, K., et al., Init. Repts. DSDP, 58: Washington (U.S. Govt. Printing Office), 783-788.

Shiono, K., 1977. Focal mechanisms of major earthquakes in southwestern Japan and their tectonic significance. J. Phys. Earth, 25: $1-26$.

Shiono, K., Sacks, I. S., and Linde, A. T., 1980. Preliminary velocity structure of Japanese Islands and Philippine Sea from surface wave dispersion. Carnegie Inst. Washington Year Book, 79:498-505.
Shiono, K., and Sugi, N., 1985. Life of an oceanic plate: cooling time and assimilation time. Tectonophysics, 112:35-50.

Tomoda, Y., and Fujimoto, H., 1983. Roles of seamount, rise, and ridge in lithospheric subduction. In Hashimoto, M., and Uyeda, S. (Eds.), Accretion Tectonics in the Circum-Pacific Regions: Tokyo (Terra), pp. 319-331.

Uyeda, S., 1972. Heat flow. In Miyamura, S., and Uyeda, S. (Eds.), The Crust and Upper Mantle of the Japanese Area (Part 1, Geophysics): Tokyo (Earthquake Research Institute, University of Tokyo), pp. 97-105.

Uyeda, S., and Kanamori, H., 1979. Back-arc opening and the mode of subduction. J. Geophys. Res., 84:1049-1061.

Watanabe, T., Langseth, M. G., and Anderson, R. N., 1977. Heat flow in back-arc basins of the western Pacific. In Talwani, M., and Pitman W. C., III (Eds.), Island Arcs, Deep Sea Trenches, and Back-arc Basins: Washington (Am. Geophys. Union), Maurice Ewing Series, 1:137-167.

Yamano, M., Uyeda, S., Aoki, Y., and Shipley, T. H., 1982. Estimates of heat flow derived from gas hydrates. Geology, 10:339-343.

Yamano, M., Honda, S., and Uyeda, S., 1984. Nankai Trough: a hot trench? Mar. Geophys. Res., 6:187-203.

Yokota, T., Kinoshita, H., and Uyeda, S., 1980. New DSDP (Deep Sea Drilling Project) downhole temperature probe utilizing IC RAM (memory) elements. Bull. Earthquake Res. Inst. Univ. Tokyo, 55: 75-88.

Yoshii, T., 1979. Compilation of geophysical data around the Japanese Islands (I). Bull. Earthquake Res. Inst. Univ. Tokyo, 54:75-117. (In Japanese with English abstract)

Date of Initial Receipt: 9 July 1984

Date of Acceptance: 25 January 1985 